\title{
Effect of Marketing System on Sales Volume of Mango Fruit: (A Case of Selected Kebeles Guto Gida Woreda
}

\author{
Dame Yemane Adula ${ }^{1} \quad$ Gudata Abara Chali ${ }^{2}$ \\ 1.Lecturer, Department of Management, College of Business and Economics, Rift Valley University, Ethiopia \\ 2.Assistant professor, Department of Accounting and Auditing, Faculty of Business and Development, Wollega \\ University, Ethiopia
}

\begin{abstract}
The major objectives of this study were assessing the effect of marketing system on sales volume of mango fruit. Data was collected from 369 (155 households were from a member of mango fruit cooperatives and 214 were not) mango producing households through questionnaire, and focus group discussion with selected 4 cooperative leaders from different kebeles, manager of mango fruit union, 4 mango producers who aren't a member of mango fruit cooperatives and 2 representatives of Guto Gida Woreda Agricultural office. Thematic content analysis was used to analyze data collected through focus group discussion. In addition to this, OLS (Multiple linear regression models) were used to analyze factors that affect sales of mango fruit. Finally, it was found that all specified dependent variables (price, distribution, and promotion) determine sales volume of mango fruit and mango fruit producers who aren't a member of cooperatives were facing much more problems than farmers under cooperative in marketing there produce.
\end{abstract}

Keywords: marketing system, price, distribution, promotion, cooperatives

DOI: $10.7176 / \mathrm{JMCR} / 56-01$

Publication date:May $31^{\text {st }} 2019$

\section{Introduction}

Mango is a highly seasonal tropical fruit, very popular among millions of people in the tropics. It also occupies a prominent place among the best fruits of the world. However, it is in constant demand, there is a pre-harvest scarcity and at times a post-harvest glut for this fruit. In Sub-Saharan Africa (SSA), growing both domesticated and wild fruit species on farms diversifies the crop production options of small-scale farmers and can bring significant health, ecological and economic revenues (FAO, 2009).

Mangoes are tropical/sub-tropical fruit with a highly significant economic importance. Mango consumers are convinced by its good flavor, delicacy, and nutrient value, and domestic demand is strong. Mango producers tend to increase production due to the sustained and favorable income generated. There is the potential to increase mango exports to many countries, with strong demand for mango products in the Middle East and Europe. Marketing plays an important role not only in stimulating production but also in accelerating the pace of economic development (Nega, Teshale, and Amanuel, 2011).Therefore, this study was conducted to assess the effect of marketing system on mango fruit sales volume in selected kebeles of GutoGidaworeda.

\section{Methodology of the study}

The researchers used descriptive research design to describe the real practice of marketing system and major problems of marketing system of mango fruit in selected kebeles. In addition to this, the researchers were used Causal research design to determine the cause and effect relationship between the variables.

The researchers used primary and secondary types of data from different sources. The primary Data sources for this study were producers of mango fruit (farmers) in selected kebeles of Guto Gida selected cooperative leaders, Guto Gida woreda agricultural office, and union. Secondary data were collected from Guto Gida Woreda Agricultural office.

Based on mango producers, we classified kebeles in Guto Gida Woreda as who are under mango fruit cooperative and out of cooperative. There are 74 rural kebeles in Guto Gida woreda, 28 of them are included under mango fruit cooperatives and the remaining 46 kebeles were not. As we know $25 \%$ of total population is representative, so based on this we select 19 kebeles among 74 which means:

$74 / 4=18.5 \approx 19$ kebeles.

To determine number of kebeles selected in each group we were used ratio as follows:

Kebeles included under mango fruit cooperatives

$74=100 \%$

$28=$ ?

$$
\frac{28 * 100}{74}=37.8 \approx 38 \%
$$

19 kebeles $* 38 \%=7.22 \approx 7$ kebeles from kebeles included under cooperative

Kebeleswho are not included in mango fruit cooperatives

$74=100 \%$ 
$46=?$

$$
\frac{46 * 100}{74}=62.16 \approx 62 \%
$$

19 kebeles $* 62 \%=11.78 \approx 12$ kebeles

According to, data available from Guto Gida woreda Agricultural office(2007/2008 E.C.) Under selected 19 kebeles there are 4783 households, and 2005 are from kebeles included under cooperative and the remaining 2,778 out of cooperative.

This study were used a simplified formula provided by Yemane (1967) to determine the required sample size at $95 \%$ confidence level.

$$
\begin{aligned}
& \mathrm{n} .=\frac{N}{1+N e^{2}} \\
& \mathrm{n}=\frac{4783}{1+4783^{*} \cdot 05^{2}}=369
\end{aligned}
$$

Where:

n- Is the sample size

$\mathrm{N}$ - The population size (number of farmers who produce mango in different kebeles)

e- The level of precision.

To determine number of households in each group

From KebelesUnder cooperatives

$4783=100 \%$

$$
2005=? \quad \frac{2005 * 100}{4783}=41.91 \approx 42 \%
$$

$369 * 42 \%=154.98 \approx 155$ household

From kebelesOut of cooperatives

$4783=100 \%$

$2778=? \quad \frac{2778 * 100}{4783}=58.08 \approx 58 \%$

$369 * 58 \%=214$ households

Sample size from each kebele was calculated proportionally.

Stratified random sampling method was used, because there are two groups of mango fruit producers (farmers who incorporated in the cooperative and the others not). And then Simple random sampling was used to select respondents from the strata. The primary data was collected using both focus group discussion, and semi structured questionnaire. The survey data wereencoded to MS-Excel file, and transferred to SPSS version 20. Both descriptive statistics and inferential statistics were employed.For analyzing the collected data throughfocus group discussion thematic content analysis was done by dividing the data in to themes or categories.

Before piloting the questions validity were checked by experts. Adjustments were made regarding readability, relevance, language and comprehension. To confirm the internal reliability, the statistical software package, SPSS, were used to determine the Cronbach's alpha values, and it became 62.4.

\section{Results and discussion}

Descriptive analysis for dependent and independent variables

Table 1. Mango fruit sales price

\begin{tabular}{lll}
\hline Variable description & mean & Std. Deviation \\
\hline I know sales price of mango at market before I sale my mango fruit & 2.15 & 1.125 \\
I decide sales price of mango fruit & 1.43 & .716 \\
Sales price of mango determined by demand and supply at market & 3.10 & 1.461 \\
Sales price of mango fruit determined by buyers & 3.59 & 1.062 \\
Sales price of mango determined by buyers and sellers negotiation & 2.73 & 1.375 \\
Union determine sales price of mango & 2.95 & 1.723 \\
Sales price of mango determined by mango fruit cooperative & 1.92 & 1.445 \\
I sale in cash & 4.51 & .501 \\
I sale in credit & 1.74 & .767 \\
I sale in advance payment & 1.74 & .623 \\
\hline
\end{tabular}

Source: Own survey, 2019

Generally, our finding about pricing variable is that there is no central unit who provide fair price information continuously for farmers and they lobbied their benefit by others with false price information. As the area is known in mango fruit produce and majority of farmers produce mango fruit, failing to provide them price information leads to discouraged them for producing it. union by itself provide price information for its members only, which is not enough as compared to number of farmers who did not included under it. Concerning about price 
determination, mango fruit producers are not still owner for their product price to decide on it. They are the one who left their land for cultivating mango fruit other than producing crops or different materials which may benefit them in different ways, but they are not owner on their produce to determine price. Others (buyers, brokers ...) determine price for farmers produce in a way that, not farmers get advantage from it rather in a way that buyers benefit from buying with unfair or least price. In addition to this, most of mango fruit producer's sale their produce in cash and others few in number sale in credit and advance payment, and here the issue of whether buyers return money at time agreed or not have to raise.

Table 2.Mango fruit sales place (distribution)

\begin{tabular}{lll}
\hline Variable description & mean & Std. Deviation \\
\hline I sale for consumers directly & 2.95 & 1.500 \\
I sale for wholesalers & 2.76 & 1.556 \\
I sale for retailers & 2.33 & 1.193 \\
I sale directly through union & 2.67 & 1.594 \\
I sale through brokers & 3.29 & 1.383 \\
I sale mango fruit on farm (tree) & 2.53 & 1.566 \\
I sale at market & 2.59 & 1.222 \\
I use cart to bring mango at market & 1.31 & .763 \\
I use car to bring mango at market & 1.47 & 1.035 \\
I carry on my back to bring mango at market & 3.14 & 1.538 \\
\hline
\end{tabular}

Source: Own survey, 2019

In general, concerning about to whom farmers sale their mango fruit, or distribution channel, most of them sale through brokers, and followed by selling directly to consumers. In relation with place where to sale mango fruit, most of them sale by bringing their product to market, and followed by selling on farm/tree. The last issue here was transportation service: and most of respondents agreed on that they carry on their back to bring their product to market. It might be one cause for minimum sales volume.

Table3. Mango fruit sales promotion

\begin{tabular}{lll}
\hline Variable description & mean & Std. Deviation \\
\hline I sale in discount & 3.72 & .741 \\
I gave extra mango & 4.49 & .501 \\
I gave free price mango & 4.33 & .470 \\
I advertise my mango to increase my sale & 2.19 & .877 \\
\hline
\end{tabular}

Source: Own survey, 2019

Finally, results indicate that most of respondents perform things/ways what we consider as promotional tools for agriculture on farm products. Whether it increase their sales volume or not, knowingly or unknowingly by selling mango with discount can promote ones product to buyers than who did nothing for attracting buyers. Not only this but also most of them gave extra mango when buyers come to farmers to buy mango, which initiate buyers to buy frequently from such sellers. In addition to this, they gave also free price mango for whom who did not come to buy mango from them, which means when one receive ones mango from farmers in other time when they want to buy, they go to the one who gave them free price mango. So even though farmers/ mango fruit producers do not recognize activity of advertising, they already did it. But from this result we understand that minimum sales volume of farmers mango were not the issue of advertising their product to the surrounding community because almost all farmers at least have 1 mango tree in their house so supply of mango is excess in Guto Gida and surrounding woredas rather the issue is promoting their mango fruit to the vast community in Ethiopia and other countries to have enough market for their product.

Table 4.Mango fruit sales volume

\begin{tabular}{lll}
\hline Variable description & mean & Std. Deviation \\
\hline I sale all mango produce & 1.45 & .598 \\
I sale majority of mango produce & 2.88 & 1.062 \\
I sale half of mango produce & 3.12 & .875 \\
I sale less than half mango produce & 3.29 & .760 \\
I never sale mango produce & 2.53 & .561 \\
\hline
\end{tabular}

Source: Own survey, 2019

Generally, concerning about sales volume that each respondents experience, most of them sale less than half, and followed by selling half from what they produce. Even their exist respondents who insure occasion of not selling what they produce. But selling all is somewhat rare as per respondents' experience, but there are respondents who have experience of selling majority of their produce. 


\section{Results of Inferential Statistics}

Table 5. Correlations

\begin{tabular}{|ll|r|r|r|r|}
\hline & & Sales volume & Promotional tools & Distribution channel & price \\
\hline \multirow{3}{*}{ Sales volume } & Pearson Correlation & 1 & $.294^{* *}$ & $.351^{* *}$ & $-0.482^{* *}$ \\
& Sig. (2-tailed) & & .000 & .000 & .000 \\
& $\mathrm{~N}$ & 369 & 369 & 369 & 369 \\
& Pearson Correlation & & 1 & $.299^{* *}$ & $.560^{* *}$ \\
Promotional tools & Sig. (2-tailed) & & .000 & .000 \\
& N & & 369 & 369 \\
\multirow{2}{*}{ Distribution channels } & Pearson Correlation & & & $.159^{* *}$ \\
& Sig. (2-tailed) & & .002 \\
& Pearson Correlation & & & 369 \\
pricing & Sig. (2-tailed) & & & 1 \\
& $\mathrm{~N}$ & & & 369 \\
\hline
\end{tabular}

Table5. **. Correlation is significant at the 0.01 level (2-tailed).

Source: Own survey, 2019

The above table shows that all independent variables promotional tools, distribution channels, and pricing have significant correlation with sales volume at $(\mathrm{P}<0.01)$. The result ensures that relationships among independent variables are free from multicollinearity issues.

\section{Results of Regression Analysis}

Variables that have strong correlation with dependent variable and variables with insignificant correlation omitted and variables that are free from multicollinearity entered into SPSS to regress variables. The model summary table shows that: Multiple correlation coefficient $(\mathrm{R})=.656, R^{2}=.430$, Adjusted $R^{2}=.409$, and it means that the dependent variable (sales volume) $41 \%$ of the variance determined from promotional tools, product pricing, distribution channels, and other listed extraneous variables which listed in the below table. In addition to this, Adjusted $R^{2}$ tells us that we have fairly good model. The ANOVA table displays that $\mathrm{F}=20.605$ and it is significant. This indicates that the combination of the independent variables significantly determine sales volume (our model can determine sales volume significantly).

The following table display coefficients:

\section{Coefficients}

\begin{tabular}{|l|r|r|r|r|r|}
\hline \multirow{2}{*}{ Model } & \multicolumn{2}{|c|}{ Unstandardized Coefficients } & Standardized Coefficients & \multirow{2}{*}{$\mathrm{t}$} & \multirow{2}{*}{ Sig. } \\
\cline { 2 - 5 } & \multicolumn{1}{|c|}{$\mathrm{B}$} & Std. Error & Beta & & \\
\hline (Constant) & 1.877 & .138 & .051 & 1.136 & .000 \\
Age & .012 & .011 & .257 \\
Marital status & .073 & .019 & .182 & 3.888 & .000 \\
Family size & -.005 & .017 & -.013 & -.260 & .795 \\
Farm experience & .022 & .009 & .108 & 2.303 & .022 \\
Land size & .042 & .017 & .127 & 2.497 & .013 \\
Farmers group & .208 & .030 & .319 & 7.045 & .000 \\
Promotional tools & .154 & .029 & .240 & 5.261 & .000 \\
Distribution channels & .342 & .039 & .466 & 8.783 & .000 \\
Pricing & .312 & .048 & .336 & 6.548 & .000 \\
\hline
\end{tabular}

Source: Own survey, 2019

All independent variables including Promotional tools, Distribution channels, and pricing are significantly contributing to sales volume. The Unstandardized coefficient of independent variables shows that the increasing or decreasing of sales volume depend or goes in line with activities of each independent variables.

As per the value that we sought at standardized beta coefficient, distribution or place contribute more to predict sales volume with (beta $=.466 \& \mathrm{P}<0.01)$. And followed by sales pricing $(\mathrm{b}=-.336 \& \mathrm{P}<0.01)$, farmers group $(\mathrm{b}=.319 \& \mathrm{P}<0.01)$, promotional tools $(\mathrm{b}=.240 \& \mathrm{P}<0.01)$, marital status $(\mathrm{b}=.182 \& \mathrm{P}<0.01)$, land size $(\mathrm{b}=.127$ $\& \mathrm{P}<0.05)$, farm experience $(\mathrm{b}=.108 \& \mathrm{P}<0.05)$. Age and family size are not significant.

\section{Results of focus group discussion}

As participants in focus group discussion described that the producers(farmers) who are not the member of the 
union they didn't set the price of mango product the price fix by brokers and trader who buy the mango product .for the producers who are the member of the union the union set the price of the mango products. As the participants in focus group discussion declare that the farmers who are the member of union sell their product by fair price rather than the producers who are not the member of union. Generally they declare that the producer's sale their products by low price due to this they didn't get benefit from mango product specially the producers who are not the member of the union.The Major Problems Regarding Selling of Mango fruit, as participants of focus group discussion indicate, the following are basic problem in selling of mango fruit: Marketing Related problems, Transportation problems, Problems Encountered during Post Harvest Process (pests and disease), Problems In supply of Chemicals and Fertilizers, Lack of support from government, stiff competition specifically union with brokers.

\section{Conclusion and Recommendations}

As per the findings that we discussed above, we can conclude that promotional tools, distribution channels, and product pricing determine sales volume of mango fruit. There are many problems in relation with these variables. The existence of problems including lack of market price information, loss of ownership on determining price for their product, lack of legal intermediaries in the market, lack of transportation, absence of nearby market, insufficient application of promotional tools make those variables to decline sales volume of mango fruit, and as a result, mango fruit producers are not beneficiaries of their product. In addition to this, from the existed two groups of mango fruit producers, farmers who incorporated under mango fruit cooperatives through union have more advantage to get market access, and price informationthan who are not included under cooperatives. Based on the above findings we recommend that:

$>$ Establish mango processing factory here in Guto Gida main town as it is central to all surrounding rural kebeles,

$>$ Create new cooperatives for farmers who are not included in existed cooperatives under union,

$>$ Central System has to be developed to set price, and provide price information for farmers,

$>$ Strengthen the existed union to take advantage in different ways,

$>$ Legalize intermediaries to make them accountable for their doings,

$>$ Oromia regional state also has to initiate investors to invest on mango, and create awareness for Mango produced in the region

$>$ As the area is potential for mango fruit production government has to work on fulfilling infrastructure especially, transportation, and central market place for sale in each kebeles.

\section{References}

Aigbiremolen, (2004). "Marketing Banking Services in Nigeria, Lagos: CIBN Press Limited. "American Marketing Association Conference Proceedings, 10,222-224,

Aaker, D.A. and Keller, K.L. (1990). "Consumer Evaluations of Brand Extensions." Journal of marketing Research, Vol. 31, pp 243-62.

Anderson and Vince, (2000). Principles of marketing, 1st Ed, Oxford University press NewYork.

Andrew E. (2001). "Marketing: Romantic or Realistic?" Marketing research, summer, pp. 40-42.

Armstrong G, (2009). Marketing in the innovative firm, London.

Chalachew Adege. (2010). marketing strategy practices, Addis Ababa University Ed. New Jersey, NJ

Engle F, (2009). Brand management: research, theory and practices, Rout edge

Fuller. (1999). Sustainable marketing: strategies playing in the background.

Harker M, (2009). Marketing: An introductory, Business and Economics. Prentice Hall.

Hart, S.et.al, (2004). Navigates the new product development process, industrial management, London

Inyanga, J. (1998). Marketing for a Developing World, Owerri, Nigeria: Global Press Limited.

Jean F, (2004). Quality, Available at http;//www.The times 100.co.uk/theory Accessed

Kotler P and Armstrong G, (2010). Principles of marketing; Pearson Prentice Hall, 13th

Kotler P, (1996). Principles of Marketing, 7th Ed, Prentice- Hall.

Kotler.P. (2007). Marketing management, $12^{\text {th }}$ edition, prentice Hall Inc,

Kurtz and Boone, (2007). Principles of marketing. Central Learning India Pvt. Ltd.

Littler and Wilson. (1995). Marketing strategy, $1^{\text {st }}$ edition, Oxford, London, Boston.

McCarthy, E. J. (1960). Basic Marketing, Managerial Approach Richard D. Irwin.

McDonald, (2004). Marketing plan: How to prepare them, how to use them.6th Ed, Oxford printing press.

Mc Graw.Hillconcise Encyclopedia of engineering, 2004, Product Quality, Available at http://www.en.wikipedia.org/wiki/customer satisfaction accessed on march21, 2011.

Morden, E. (1991). Elements of Marketing, London: AP Publications. On March 15, 2011.

Palmer A, (2000). Principles of Marketing, 1st Ed, Oxford Press.

Paul Fifield. (1994). Marketing strategy, Linacre House, Jordan Hill, Oxford, 
Philip K. \& Garry A. (2007). Principles of marketing, $11^{\text {th }}$ edition, prentice Hall, Europe, Mifflin Publishing. Pride and Ferrel (1987). Marketing: Basic Concepts and Decisions (5th ed.), USA: Houghton Mittlin Company. Quality and Standards Authority of Ethiopia, December-2003 volume.4 No 5

Ranchhod, A., and Gurau, C. (2007). Marketing Strategies: A Contemporary Approach. $2^{\text {nd }}$ Edition, Prentice Hall. Rayport, J. and Sviokla, J. (1994). "Managing in the Market space." Harvard Business Review, NovemberDecember, pp. 141-50.

Tellis, G. (1986). “Beyond the Many Faces of Price: An Integration of Pricing Strategies.” Journal of Marketing, Vol. 50, October, pp. 146-160.

Walker, Boyd and Larreche, (1992). Marketing strategy: planning and implementation, USA. 